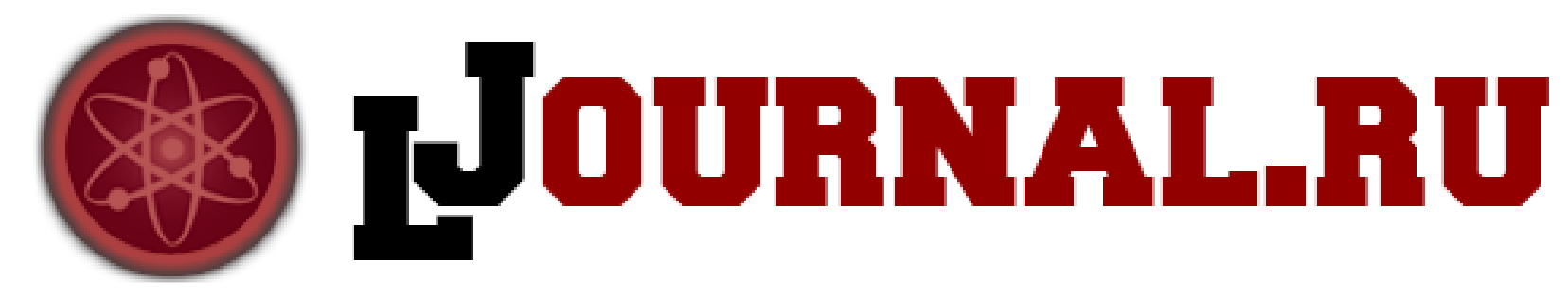

Терещук О.С., Пронина Е.А., Гоц И.Ю., Муктаров О.Д., Пичхидзе С.Я.

СГТУ им. Гагарина Ю.А.

Россия, Саратов

doi: 10.18411/lj2016-2-27

\title{
Разработка конструкции ультразвуковой насадки для очистки корневого канала и доставки лекарств
}

Для повышения качества лечения воспалительных заболеваний, локализованных в периапикальной области зубов, современные протоколы обработки корневых каналов включают сочетанное использование ультразвуковых колебаний и ирригационных растворов [1].

Цель работы: разработка конструкции ультразвуковой насадки для эндодонтической обработки; увеличение коррозионной стойкости стали X18H10T путем ее термической обработки в углеродсодержащих средах; исследование коррозионных характеристик в $3 \%$ водном растворе $\mathrm{NaCl}$.

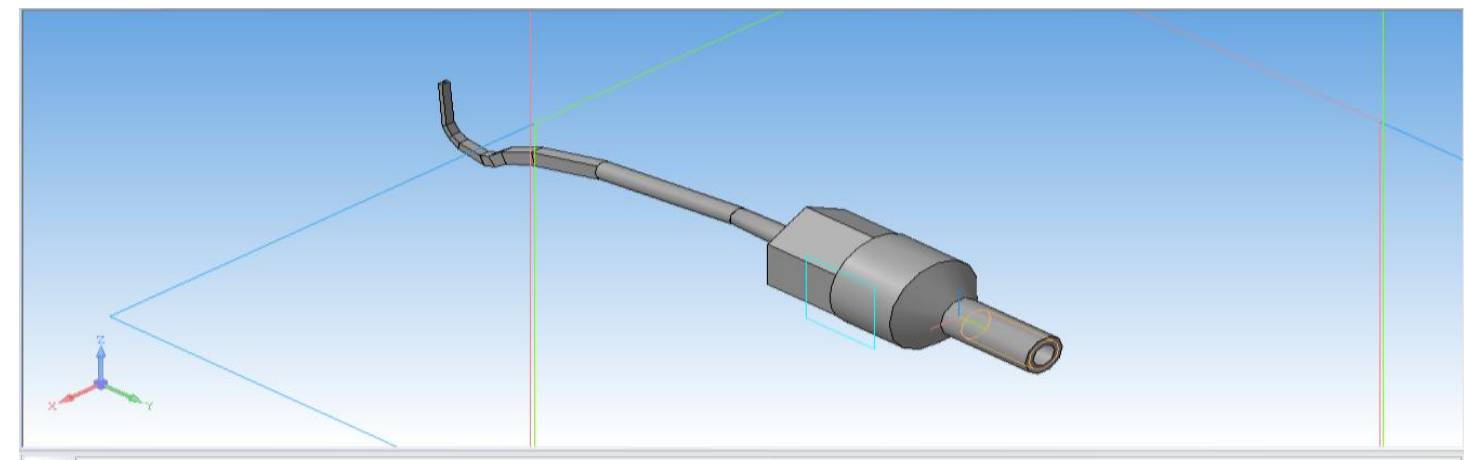

Рис.1. Конструкция ультразвукового эндодонтического наконечника

Одним из способов упрочнения стали является высокотермическая обработка и насыщение поверхностных слоев углеродом (цементация). В данной работе проведены исследования старения стали Х18Н10Т при температуре 600 
${ }^{0} \mathrm{C}$ при дополнительном насыщении ее углеродом, алюминием, фторопластами (Ф-42, Ф-2М) в течение 1 часа. Образцы представляли собой диски, общей

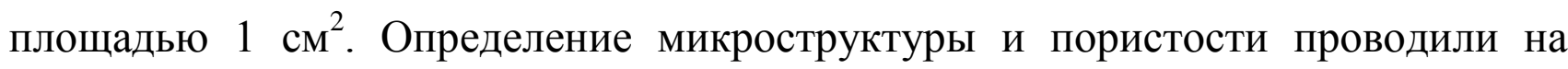
микроскопе АГПМ-6М.

Измерение микротвердости проводилось в соответствии с требованиями ГОСТ 9450-76 «Измерение микротвердости вдавливанием алмазных наконечников» под нагрузкой менее 2 Н $(200$ гс $)$ с использованием микротвердомера модели HVS-1000B. Скорость коррозии $v$ и показатель коррозии $\Pi$ определялись из гравиметрических измерений согласно ГОСТ (ГОСТ17322-71) и (ГОСТ 5272-68), при этом образцы выдерживали в 3\% водном растворе $\mathrm{NaCl}$ в течение 48 часов, табл. 1 .

Таблий 1.

Результаты физико-механических и коррозионньх измерений

\begin{tabular}{|c|c|c|c|c|}
\hline $\begin{array}{c}\text { Условия термической } \\
\text { обработки }\end{array}$ & $\begin{array}{c}\text { Пористость, } \\
\%\end{array}$ & $\begin{array}{c}\text { Микро- } \\
\text { твердость, } \\
\mathrm{HV}\end{array}$ & $\begin{array}{c}\text { Скорость } \\
\text { коррозии, } \\
\mathrm{V}, \Gamma /\left(\mathrm{M}^{2} \bullet \mathrm{ч}\right)\end{array}$ & $\begin{array}{c}\text { показатель } \\
\text { коррозии, П, } \\
\text { мм/год }\end{array}$ \\
\hline исходная & 54 & 257 & 0.083 & 0.093 \\
\hline $600^{\circ} \mathrm{C}$ & 20 & 442 & 0.167 & 0.20 \\
\hline $600^{\circ} \mathrm{C},+C$ & 27 & 127 & 0.042 & 0.05 \\
\hline $600^{\circ} \mathrm{C},+A l$ & 19 & 157 & 0.021 & 0.02 \\
\hline $600^{\circ} \mathrm{C}, \Phi-42+A l$ & 28 & 143 & 0.021 & 0.02 \\
\hline $600^{\circ} \mathrm{C}, \Phi-2 \mathrm{M}+A l$ & 12 & 144 & 0.042 & 0.05 \\
\hline
\end{tabular}

Согласно полученным данным температурная обработка при $600^{\circ} \mathrm{C}$ увеличивает твердость стали почти в 2 раза, но при этом снижается коррозионная стойкость материала, что связано с возникновением межкристаллитной коррозии и появлению очагов питинговой коррозии [2]. Введение фторопласта Ф-42 приводит к снижению микротвердости и увеличению коррозионной стойкости.

Дополнительно разработан ирригационный раствор на основе гидроксиапатита, фурациллина и адъюванта - фторированного углерода для введения в корневой канал и периапикальную область посредством УЗ колебаний. Готовится к апробации методика введения разработанного ирригационного раствора. 
Выводы: разработана конструкция ультразвуковой насадки для обработки корневого канала для очистки и доставки лекарственных препаратов в периапикальные ткани.

\section{Литература:}

1. Болячин А., Беляева Т. Ирригация системы корневого канала: современные принципы и методики. Полтава, Ж. ДентАрт, 2, 2010.-с.32-39.

2. Шубадеева Л.И., Ревякина О.К., Макарчук Т.Б., Гуревич Л.Я. Влияние нагревов на коррозионную стойкость стали 12Х18Н10Т. Ж. физико-химия поверхности и защита материалов. - т.32, №2, 1996. - 5c. 